\title{
Vortex-wide chlorine activation by a mesoscale PSC event in the Arctic winter of 2009/10
}

\author{
Tobias Wegner ${ }^{1}$, Michael C. Pitts ${ }^{1}$, Lamont R. Poole ${ }^{2}$, Ines Tritscher ${ }^{3}$, Jens-Uwe Grooß ${ }^{3}$, and Hideaki Nakajima ${ }^{4}$ \\ ${ }^{1}$ NASA Langley Research Center, Hampton, Virginia, USA \\ ${ }^{2}$ Science Systems and Applications, Hampton, Virginia, USA \\ ${ }^{3}$ Institute for Energy and Climate Research IEK-7, Forschungszentrum Jülich, Jülich, Germany \\ ${ }^{4}$ National Institute for Environmental Studies, Tsukuba, 305-8506, Japan \\ Correspondence to: Michael C. Pitts (michael.c.pitts@nasa.gov)
}

Received: 22 October 2015 - Published in Atmos. Chem. Phys. Discuss.: 30 November 2015

Revised: 13 March 2016 - Accepted: 14 March 2016 - Published: 13 April 2016

\begin{abstract}
In the Arctic polar vortex of the 2009/10 winter temperatures were low enough to allow widespread formation of polar stratospheric clouds (PSCs). These clouds occurred during the initial chlorine activation phase which provided the opportunity to investigate the impact of PSCs on chlorine activation. Satellite observations of gas-phase species and PSCs are used in combination with trajectory modeling to assess this initial activation. The initial activation occurred in association with the formation of PSCs over the east coast of Greenland at the beginning of January 2010. Although this area of PSCs covered only a small portion of the vortex, it was responsible for almost the entire initial activation of chlorine vortex wide. Observations show $\mathrm{HCl}$ (hydrochloric acid) mixing ratios decreased rapidly in and downstream of this region. Trajectory calculations and simplified heterogeneous chemistry modeling confirmed that the initial chlorine activation continued until $\mathrm{ClONO}_{2}$ (chlorine nitrate) was completely depleted and the activated air masses were advected throughout the polar vortex. For the calculation of heterogeneous reaction rates, surface area density is estimated from backscatter observations. Modeled heterogeneous reaction rates along trajectories intersecting with the PSCs indicate that the initial phase of chlorine activation occurred in just a few hours. These calculations also indicate that chlorine activation on the binary background aerosol is significantly slower than on the PSC particles and the observed chlorine activation can only be explained by an increase in surface area density due to PSC formation. Furthermore, there is a strong correlation between the magnitude of the observed $\mathrm{HCl}$ depletion and PSC surface area density.
\end{abstract}

\section{Introduction}

Heterogeneous chemistry on stratospheric aerosol and polar stratospheric clouds (PSCs) plays a crucial role in the formation of the Antarctic ozone hole (Solomon, 1999). While the stratospheric aerosol layer is present globally at all times (Junge et al., 1961), PSCs only form over the polar regions of the winter hemisphere (Lowe and MacKenzie, 2008). PSCs are ubiquitous in the Antarctic winter but wide-spread PSC occurrence over the Arctic is only observed during very cold winters (Pitts et al., 2009, 2011). PSCs have a substantial influence on the chemical composition of the polar stratosphere: on the one hand heterogeneous chemistry on PSC particles impacts the partitioning of inorganic chlorine by chlorine activation (Solomon et al., 1986), i.e., by converting inorganic chlorine reservoir species (mainly $\mathrm{HCl}$ and $\left.\mathrm{ClONO}_{2}\right)$ to photo-active species $\left(\mathrm{ClO}_{x}=\mathrm{ClO}+2 \cdot \mathrm{Cl}_{2} \mathrm{O}_{2}\right)$. On the other hand, PSC particles can grow large enough to effectively denitrify (Fahey et al., 2001) and dehydrate (Kelly et al., 1989) the lower stratosphere. Although PSCs have a pivotal role in determining stratospheric chemical composition and have been subject to extensive research since the 1980s, some details are still subject to uncertainty.

Two of the key questions are the following: (1) to which extent is heterogeneous chemistry on PSC particles responsible for chlorine activation and (2) what are the timescales for this processing? Several studies (e.g. Drdla and Müller, 2012; Wohltmann et al., 2013; Kirner et al., 2015) have suggested that the influence of PSCs on chlorine activation in subordinate to that of cold binary aerosol on a vortex-wide scale. When temperatures approach the frost point, hetero- 
geneous reaction rates are large enough to activate chlorine on timescales of minutes to hours regardless of surface type (Wegner et al., 2012). On the other hand, Carslaw et al. (1998) and Kühl et al. (2004) showed that nearly complete chlorine activation can be achieved in a mountain-wave PSC at sufficiently low temperatures and large surface area densities.

This study investigates the influence of mesoscale PSCs on the chemical composition of the entire vortex. Mesoscale PSCs are larger in spatial scale than mountain-wave induced PSCs but still only cover a small fraction of the polar vortex. We use data from the Cloud-Aerosol LIdar with Orthogonal Polarization (CALIOP, Winker et al., 2009) instrument for studying PSCs and data from the Microwave Limb Sounder (MLS, Waters et al., 2006) in combination with model calculations of the Chemical Lagrangian Model of the Stratosphere (CLaMS, McKenna et al., 2002) to examine the impact of a mesoscale PSC on the chemical composition of the Arctic vortex in January 2010. CALIOP backscatter observations are used to derive particle surface area density (SAD) which is then used to calculate chlorine activation. Through these analyses, we will examine the impact of PSC SAD enhancements on chlorine activation compared with the cold binary background aerosol.

\section{Instrumentation and model description}

The Cloud-Aerosol Lidar and Infrared Pathfinder Spaceborne Observations (CALIPSO) satellite is member of the A-train satellite constellation (Stephens et al., 2002) orbiting at an inclination of $98.2^{\circ}$ that provides coverage up to $82^{\circ}$ latitude in each hemisphere. Its primary instrument is CALIOP which measures backscatter at 1064 and $532 \mathrm{~nm}$, with the $532 \mathrm{~nm}$ channel separated into orthogonal polarization components parallel and perpendicular to the polarization plane of the outgoing laser beam. The CALIOP classification scheme distinguishes between supercooled ternary solutions (STS), mixtures of STS and nitric acid trihydrate (NAT) and ice. Mixtures of STS and NAT are further divided into three groups: MIX 1, MIX 2 and MIX 2 enhanced, in order of increasing NAT number density. CALIOP also distinguishes between synoptic and wave ice. PSCs are identified in the CALIOP measurements as enhancements in backscatter at $532 \mathrm{~nm}$ with an altitude-dependent threshold of $\beta_{532}$ between 2 and $4 \times 10^{-5} \mathrm{~km}^{-1} \mathrm{sr}^{-1}$ in the algorithm described in Pitts et al. (2013). We show sensitivity studies that use different threshold backscatter ratios between $3 \times 10^{-5}$ and $1.5 \times 10^{-4} \mathrm{~km}^{-1} \mathrm{sr}^{-1}$, where the latter backscatter threshold is high enough to indicate the presence of ice PSCs. Details about the CALIOP PSC classification algorithm can be found in Pitts et al. (2009, 2011, 2013).

The microwave limb sounder (MLS) is an instrument on the Aura satellite, which is also part of the A-train constellation and has provided nearly continuous measurements since
2004. MLS provides about 3500 profiles of gas-phase species and temperature from Earth's surface to $90 \mathrm{~km}$ altitude between $82^{\circ} \mathrm{N}$ and $82^{\circ} \mathrm{S}$ per day. In this study, we use MLS $\mathrm{HCl}$ data from retrieval version 3.3 (Livesey et al., 2011) which are comparable to version 2.2. Retrieval version 2.2 for $\mathrm{HCl}$ has been validated in Santee et al. (2008). The vertical resolution and precision of the $\mathrm{HCl}$ observations are $3 \mathrm{~km}$ and $0.2-0.3$ ppbv, respectively.

CALIOP and MLS observations are linearly interpolated to a $20^{\circ}$ by $2^{\circ}$ (longitude $\times$ latitude) grid on fixed potential temperature surfaces each day. Potential temperature is calculated from the original MLS pressure levels and temperature data from the modern-era retrospective analysis for research and applications (MERRA, Rienecker et al., 2011).

Air mass trajectories are calculated with CLaMS which uses a fourth-order Runge-Kutta scheme. The wind fields for these trajectories are taken from ERA-INTERIM (Dee et al., 2011). Threshold temperatures $T_{\mathrm{NAT}}$ (NAT existence temperature) and $T_{\mathrm{ACl}}$ (chlorine activation temperature) which can serve as indicators for chlorine activation (Drdla and Müller, 2012) are calculated with temperatures and trace gas concentration from a CLaMS simulation described in Grooß et al. (2014). The vortex edge is defined according to Nash et al. (1996).

A simple algorithm was defined to determine the locations of air masses that had previously passed through the PSC event. Trajectories are used to track air masses downwind of a PSC that is defined by the CALIOP detection threshold. These air masses are called "Processed Air" since we assume that chlorine activation predominantly occurred in such air masses. On a given day a grid box is labeled as filled with "Processed Air" if a processed air mass has passed through this grid box on that day. A grid box is then labeled as filled with "Unprocessed Air" if on a given day no processed air masses have passed through this grid box even if this grid box was marked with "Processed Air" on previous days. This way we can describe for each day the fraction of the vortex that is filled with air masses which have previously encountered a PSC.

The determination of heterogeneous reaction rates requires an estimation of the particle surface area density (SAD) of PSCs and the background aerosol as realistic as possible. Following the approach of Gobbi (1995), we performed Mie calculations for unimodal lognormal particle size distributions representative of the polar stratosphere to derive a relationship between CALIOP measurements of particulate backscatter at $532 \mathrm{~nm}$ and the liquid particle SAD. Figure 1a shows calculated liquid particle SAD and backscatter ( $\left.\beta_{532, \text { liquid }}\right)$ as a function of temperature relative to the frost point ( $T-T_{\text {frost }}$ ) for the following conditions: pressure $=30 \mathrm{hPa}, \mathrm{HNO}_{3}=15 \mathrm{ppbv}, \mathrm{H}_{2} \mathrm{O}=5 \mathrm{ppmv}$, particle number density $N=10 \mathrm{~cm}^{-3}$ (Curtius et al., 2005), and lognormal geometric standard deviation $\sigma=1.6$ (Lambert et al., 2012) which describes the width of the distribution. For these calculations, liquid particle volume was prescribed as a func- 
tion of temperature according to Carslaw et al. (1995); mode radius (for the Mie calculations) and SAD were then calculated from particle volume using standard relationships for a unimodal lognormal.

Calculated values of liquid $\mathrm{SAD}$ and $\beta_{532, \text { liquid from }}$ Fig. 1a are plotted against each other in Fig. 1b. The dashed curve shows the least-squares quadratic fit in log-log space between the two parameters, which we will use in this study. With fixed number density $N=10 \mathrm{~cm}^{-3}$ and width of $\log$ normal distribution $\sigma=1.6$, calculated points fall along the same least-squares curve for different pressure levels (50 and $70 \mathrm{hPa}), \mathrm{HNO}_{3}$ mixing ratios $(2,5$, and $10 \mathrm{ppbv})$, and $\mathrm{H}_{2} \mathrm{O}$ mixing ratio $(2 \mathrm{ppmv})$. Values calculated for different number densities $\left(N=5\right.$ and $\left.N=15 \mathrm{~cm}^{-3}\right)$ and geometric standard deviations $(\sigma=1.3$ and $\sigma=1.8)$ fall along different curves, but all points lie within the limits depicted by the solid gray curves. Given the small envelope defined by those parameters the relationship between $\mathrm{SAD}$ and $\beta_{532 \text {, liquid is }}$ robust and covers a wide range of possible conditions in the polar vortex. Measured values of $\beta_{532 \text {,liquid larger than }}$ $1.5 \times 10^{-4} \mathrm{~km}^{-1} \mathrm{sr}^{-1}$ likely signify ice PSCs. The SAD estimated using the least-squares relationship for liquid particles can be considered a lower limit of SAD for ice PSCs. The relationship between backscatter and surface area density for STS particles can then be described by

$$
\begin{aligned}
\log _{10} \mathrm{SAD} & =3.474+0.671 \cdot \log _{10} \beta_{532} \\
& +0.007 \cdot\left(\log _{10} \beta_{532}\right)^{2} .
\end{aligned}
$$

\section{The mesoscale PSC event}

Near the end of December 2009, CALIOP observed an increase in backscatter over Greenland, corresponding to the first major formation of liquid and ice PSCs (Pitts et al., 2011) during the Arctic winter 2009/10. The increase in SAD indicates condensation of $\mathrm{HNO}_{3}$ on the background aerosol or the nucleation of NAT and ice particles. The PSC backscatter and areal extent increased during the following 2 days reaching a maximum on 2 January 2010 before slowly decreasing on subsequent days. Figure 2 shows the PSC classification according to Pitts et al. (2011) from the CALIOP observations on 2 January. The PSC extends between 20 and $25 \mathrm{~km}$ in altitude and is a mixture of all PSC types. CALIOP observations indicate that STS forms first over the west coast of Greenland followed by wave ice formation over central Greenland. Synoptic ice and NAT mixtures occur downstream of the wave ice over eastern Greenland. While Fig. 2 represents only a snapshot of the PSC, it also provides information about the temporal evolution of PSC particles. The temporal evolution of PSC particles within a confined air mass will look very similar to the geographical distribution depicted in Fig. 2, with STS forming first, followed by ice
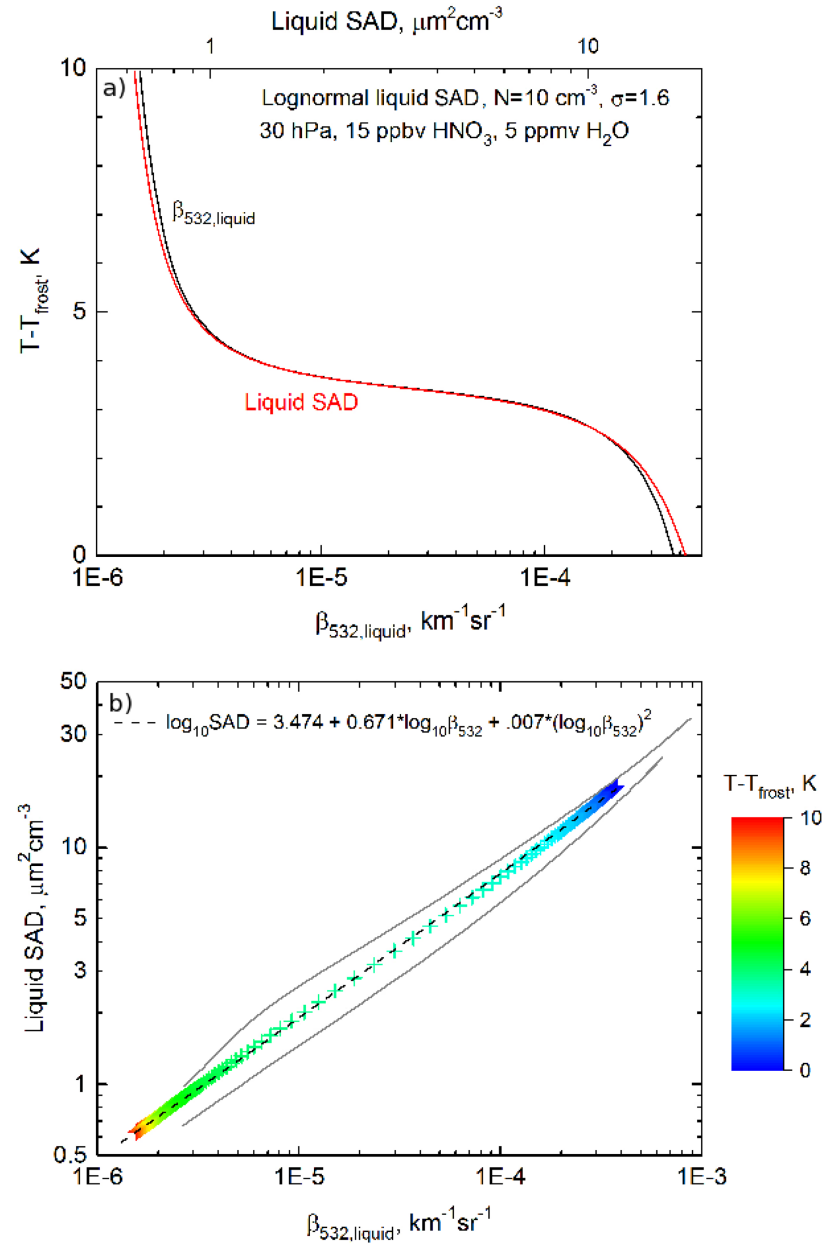

Figure 1. (a) Temperature dependence of STS surface area density (top $x$ scale) and the corresponding theoretical backscatter signal at $532 \mathrm{~nm}$ for typical stratospheric conditions. (b) Relationship between STS surface area density and particulate backscatter color coded according to their theoretical temperature. Gray curves mark the deviation from the fitted function for varying ambient conditions.

and NAT particles. Figure 2 also shows the limitations of our current observations with gaps of hundreds of kilometers between the orbits. During this PSC event, the vortex was shifted away from the pole over northeast Canada and northern Russia. The vortex remained stable during this time frame with only limited dynamic disturbances.

Figure 3 shows backscatter over a 6-day period from 31 December 2009 to 5 January 2010 and the prevailing winds. From the meteorological data we estimate the wind speed in the vicinity of the PSC to be $20 \mathrm{~m} \mathrm{~s}^{-1}$ which yields a residence time of about 1 day for air parcels traveling through the PSC. Chlorine activation is limited by the availability of the reservoir species and will cease once either $\mathrm{HCl}$ or $\mathrm{ClONO}_{2}$ are depleted (Portmann et al., 1996). Heterogeneous chemistry on stratospheric aerosols is primarily the 


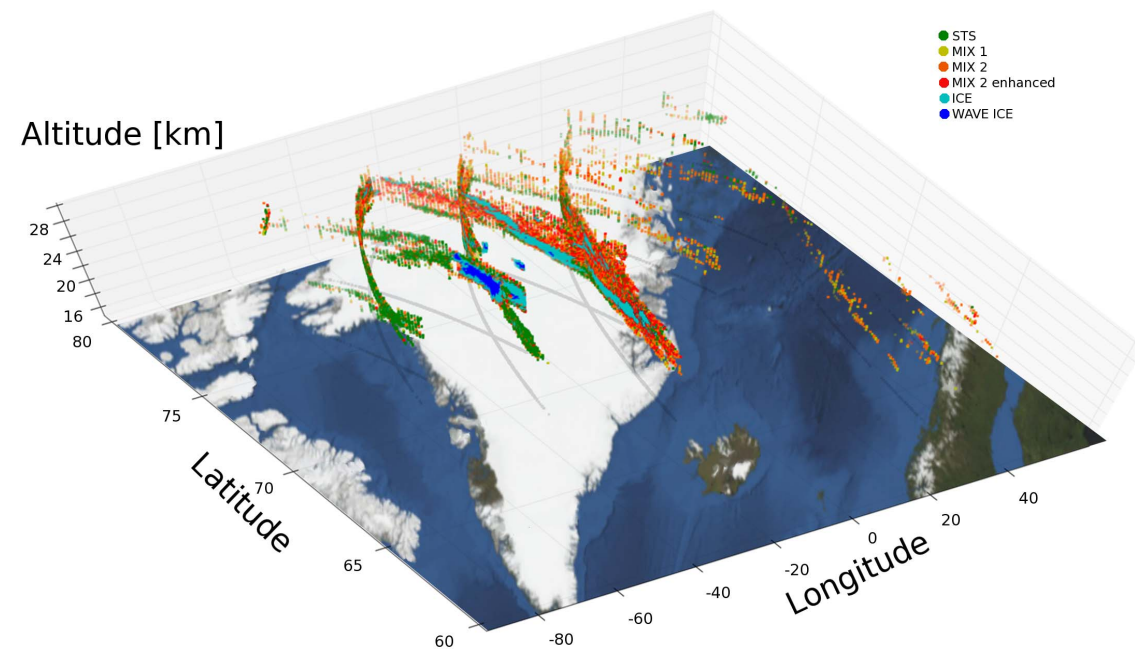

Figure 2. CALIOP PSC observations along orbits over Greenland on 2 January 2010 color coded according to the CALIOP classification. Green: STS; Yellow: MIX 1; Orange: MIX 2; Red: MIX 2 enhanced; Cyan: Synoptic Ice; Blue: Wave Ice

conversion of $\mathrm{HCl}$ and $\mathrm{ClONO}_{2}$ into $\mathrm{ClO}_{x}\left(\mathrm{ClO}+2 \cdot \mathrm{Cl}_{2} \mathrm{O}_{2}\right)$. Therefore, the observations of gas-phase $\mathrm{HCl}$ by MLS can serve as an indicator of heterogeneous processing with low values of $\mathrm{HCl}$ indicating air masses where inorganic chlorine has been activated. Since $\mathrm{HCl}$ is more abundant than $\mathrm{ClONO}_{2}$ at the beginning of winter, $\mathrm{ClONO}_{2}$ is the limiting component in chlorine activation (Portmann et al., 1996).

Figure $3 \mathrm{a}$ shows that low $\mathrm{HCl}$ mixing ratios are co-located with the PSCs over northern Greenland on 31 December and that $\mathrm{HCl}$ mixing ratios upstream of the PSC are more than twice as high compared to air exposed to the PSC. CALIOP observed backscatter values above $1.5 \times 10^{-4} \mathrm{~km}^{-1} \mathrm{sr}^{-1}$ which corresponds to a tenfold increase of SAD relative to background conditions, or to around $10 \mu \mathrm{m}^{2} \mathrm{~cm}^{-3}$. During all subsequent days, $\mathrm{HCl}$ is always lower in the vicinity of PSCs compared to areas upstream with $\mathrm{HCl}$ mixing ratios decreasing to less than $0.5 \mathrm{ppbv}$ during this period, about a quarter of their values in a chemically unperturbed vortex.

The low $\mathrm{HCl}$ mixing ratios persist downstream of the PSCs and do not decrease further, in agreement with current knowledge that chlorine activation is highly dependent on SAD, temperature and the ratio of $\mathrm{HCl} / \mathrm{ClONO}_{2}$. Model calculations (not shown) indicate that $\mathrm{ClONO}_{2}$ is totally depleted downstream of the PSC. Additional activation can only occur when $\mathrm{ClONO}_{2}$ is regenerated (Portmann et al., 1996). $\mathrm{ClONO}_{2}$ controls the total amount of chlorine that can be activated while PSCs determine the area in which activation occurs. Low $\mathrm{HCl}$ concentrations observed in regions where our calculations indicate that only unprocessed air is present, could originate from either physical mixing with processed air or averaging along the MLS field of view. We also need to stress that such trajectory calculations rely on the quality of the wind fields used and are subject to errors which are difficult to quantify.
The air which was exposed to PSCs on 31 December 2009 (Fig. 3a, enclosed by red and blue contour lines) has completed a full circumnavigation of the vortex after 5 days (5 January 2010, Fig. 3f) and re-entered the region where it first encountered PSCs. Air which was not exposed to PSCs tends to have higher $\mathrm{HCl}$ mixing ratios, indicating that little chlorine activation occurred outside of PSCs, as shown clearly, for example, on 2 January in Fig. 3c. Air between Norway and Novaya Zemlya followed its own cyclonic circulation separate from the polar vortex. Air in this region did not encounter PSCs nor sunlight, leading to constant $\mathrm{HCl}$ mixing ratios. This situation persisted for several days and the trajectories passing through PSCs actually flowed around this region. After 3 January (Fig. 3d-e) air with low $\mathrm{HCl}$ mixing ratios flows into the PSC covered area from the unobserved area north of $82^{\circ}$ so we do not have a complete history of $\mathrm{HCl}$ concentrations in relation to PSC exposure for these air masses.

As Fig. 3 indicates, it takes about 5 days for air masses to circumnavigate the polar vortex. This means that a PSC with a sufficiently large meridional extent can activate chlorine throughout the entire vortex even when the PSC itself only covers a small fraction of the vortex. Such a PSC can serve as a "processing reactor" for chlorine activation with heterogeneous chemistry basically limited to the time air masses spend inside the PSC. Vortex-averaged $\mathrm{HCl}$ mixing ratios which are commonly used to estimate chlorine activation would not accurately represent the true nature of activation within the vortex, under these conditions.

While chlorine activation is generally observed within the boundary of elevated backscatter values as observed by CALIOP, the lowest $\mathrm{HCl}$ mixing ratios are correlated with the highest backscatter values. Figure 4 shows the ratio of mean $\mathrm{HCl}$ mixing ratios in processed air which has been ex- 
(a) 31 Dec 2009

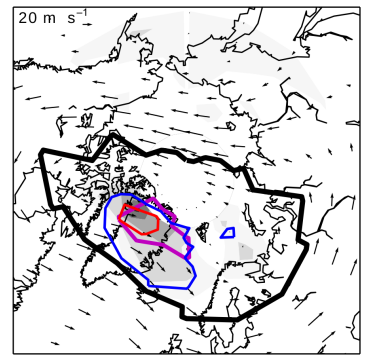

(b) 01 Jan 2010

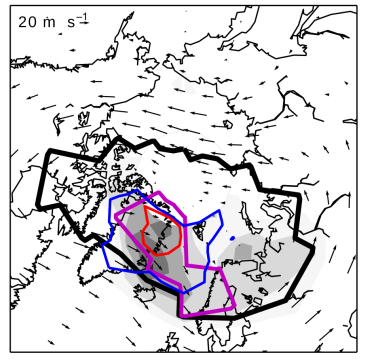

(c) 02 Jan 2010

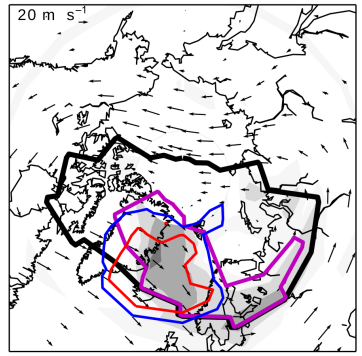

Figure 3. The meteorological situation over a 6-day period from 31 December 2009 to 5 January 2010 for the Arctic winter $2009 / 2010$ on the $510 \mathrm{~K}$ isentrope (approximately $22 \mathrm{~km}$ ). Arrows show the prevailing wind direction and speed. The vortex edge is calculated according to Nash et al. (1996) and shown in solid black. Solid magenta indicates regions of the vortex with air which has passed through a PSC. Blue and red contours show the particulate backscatter from CALIOP where blue represents the detection limit for CALIOP $\left(3 \times 10^{-5} \mathrm{~km}^{-1} \mathrm{sr}^{-1}\right)$ and red values are indicative of PSCs with a surface area density of more than 10 times the background values $\left(1.5 \times 10^{-4} \mathrm{~km}^{-1} \mathrm{sr}^{-1}\right)$. Gray contours show $\mathrm{HCl}$ mixing ratios from MLS.

posed to backscatter values above certain thresholds to the vortex average $\mathrm{HCl}$ mixing ratio. The backscatter thresholds in Fig. $4 a-c$ indicate the formation of STS. Figure 4d suggests the presence of ice since backscatter values of this magnitude correspond to higher surface area densities than physically possible with only the condensation of $\mathrm{HNO}_{3}$.

The ratio of mean $\mathrm{HCl}$ mixing ratios to the vortex average $\mathrm{HCl}$ mixing ratio is also shown for air which has been exposed to temperatures below either $T_{\mathrm{NAT}}$ or $T_{\mathrm{ACl}}$. After 5 days the $\mathrm{HCl}$ mixing ratios within processed air are indistinguishable from the vortex mean (indicated by the white contour on the right side of each panel) because all air within the vortex has been exposed to PSCs. With smaller threshold backscatter values chosen for the area describing the "processing reactor" (Fig. 4d to a), $\mathrm{HCl}$ mixing ratios in air which has been exposed to PSCs gradually approach the vortex average. This shows that chlorine activation occurs locally in the area covered by PSCs but not on a vortex-wide scale.

Temperature thresholds for chlorine activation do not capture this localized effect. The air exposed to an area enclosed by a temperature threshold is always very similar to the vortex average since those areas already encompass the main part of the vortex. Therefore, neither $T_{\mathrm{NAT}}$ nor $T_{\mathrm{ACl}}$ provide realistic information on the location where chlorine activation occurs for the period considered in this study. Only thresholds based on backscatter provide this information.

In addition, Fig. 4 indicates that at the beginning of the activation phase under study, the average $\mathrm{HCl}$ mixing ratio in the area above a chosen backscatter threshold decreases as the backscatter threshold is increased. Since backscatter can be used as a proxy for surface area density, the surface area provided by PSCs appears to have a direct affect on gasphase $\mathrm{HCl}$ concentrations. While $\mathrm{HCl}$ mixing ratios above a backscatter threshold indicative of STS (Fig. 4a) have a minimum of $70 \%$ of vortex average $\mathrm{HCl}$ mixing ratios, $\mathrm{HCl}$ mixing ratios above a threshold suggestive of ice PSCs (Fig. 4d) have a minimum of $50 \%$ of the vortex average $\mathrm{HCl}$ mixing ratios. Therefore, chlorine activation processes visibly faster with increasing surface area density. The magnitude of chlorine activation appears to be correlated with available surface area density provided by PSCs.

The mesoscale PSC event leaves a visible mark on $\mathrm{HCl}$ mixing ratios. When separating the polar vortex into regions of processed and unprocessed air, we find lower $\mathrm{HCl}$ mixing ratios in processed air (Fig. 5) between 31 December and 9 January. Observations by MLS show that for all days between 20 and $25 \mathrm{~km}, \mathrm{HCl}$ is lower in processed air compared to unprocessed air. However, the large uncertainties indicate that the distinction between processed and unprocessed air is difficult and that the mean values are calculated from heterogeneous air masses. Still, we see a clear trend that chlorine activation has progressed further in air masses which have been exposed to PSCs.

The analysis for Fig. 5 was repeated with $T_{\mathrm{NAT}}$ and $T_{\mathrm{ACl}}$ (not shown) as indicators for processed air. Here, processed air describes those grid boxes with temperatures less than the respective threshold temperatures and grid boxes where trajectories are present which have encountered temperatures less than the temperature thresholds in their past. Two main differences emerge. First, the daily mean mixing ratios for processed and unprocessed air are more similar, making a distinction between them difficult. Second, processed air covers the entire vortex more quickly because both temperature thresholds cover a larger area of the vortex than our PSC threshold. This leads to fewer available data points. Using either of the temperature thresholds to describe processed air 


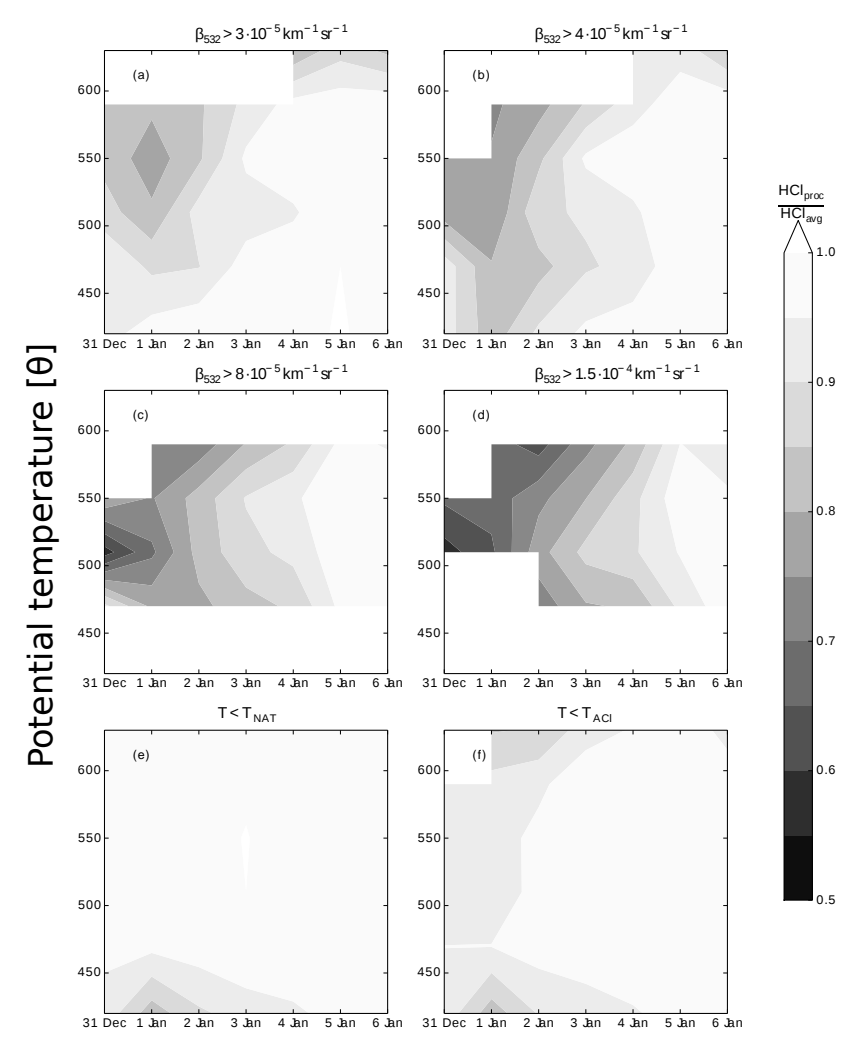

Figure 4. Ratio of average $\mathrm{HCl}$ mixing ratio of air that passed through a specified area to the vortex average $\mathrm{HCl}$ mixing ratio. The ratio is calculated for six areas, four encompassed by backscatter thresholds (a-d) and two by temperature thresholds $\left(T_{\mathrm{NAT}}, \mathbf{e}\right.$ and $\left.\mathrm{T}_{\mathrm{ACl}}, \mathbf{f}\right)$. A ratio of less than one indicates air inside the contour has a lower $\mathrm{HCl}$ mixing ratio than the vortex average.

does not show any significant difference between processed and unprocessed air.

\section{Modeling heterogeneous chemistry}

For a quantitative understanding of the shown $\mathrm{HCl}$ decrease we use the trajectories combined with a very simplified heterogeneous chemistry scheme. Using the relationship in Eq. (1), we can use CALIOP backscatter to calculate PSC SAD along trajectories passing through the maximum PSC backscatter. The trajectories are initialized with $\mathrm{H}_{2} \mathrm{O}, \mathrm{HNO}_{3}$ and $\mathrm{HCl}$ from MLS observations and it is assumed that at the start of the trajectories no chlorine has been activated yet. Hence, $\mathrm{ClONO}_{2}$ is initialized as the difference between total inorganic chlorine $\left(\mathrm{Cl}_{y}\right)$ and $\mathrm{HCl}$ with $\mathrm{Cl}_{y}$ derived from the $\mathrm{Cl}_{y}-\mathrm{N}_{2} \mathrm{O}$ tracer-tracer relationship (Grooß et al., 2002). The simplified chemistry consists of three heterogeneous reactions which are modeled along the trajectories:

$\mathrm{HCl}+\mathrm{ClONO}_{2} \longrightarrow \mathrm{Cl}_{2}+\mathrm{HNO}_{3}$

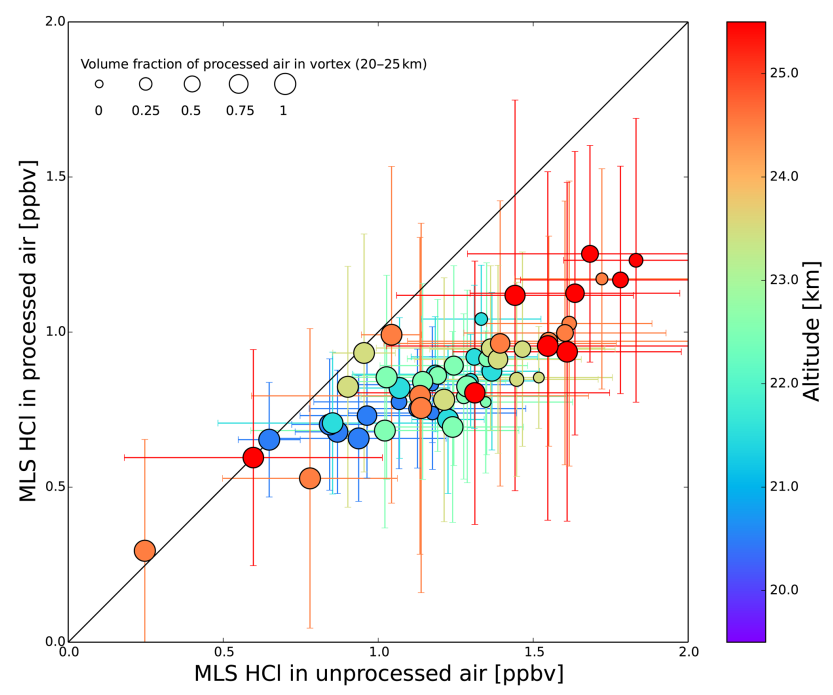

Figure 5. Correlation of daily average MLS $\mathrm{HCl}$ in processed (Backscatter threshold: $3 \times 10^{-5} \mathrm{~km}^{-1} \mathrm{sr}^{-1}$ ) and unprocessed air from 31 December to 9 January for six different altitudes. Error bars indicate the $1 \sigma$ standard deviation of calculating the daily average $\mathrm{HCl}$ mixing ratios.

$\mathrm{ClONO}_{2}+\mathrm{H}_{2} \mathrm{O} \longrightarrow \mathrm{HOCl}+\mathrm{HNO}_{3}$

$\mathrm{HCl}+\mathrm{HOCl} \longrightarrow \mathrm{Cl}_{2}+\mathrm{H}_{2} \mathrm{O}$.

No additional reactions are included in the calculations since they are not relevant to assess chlorine activation on timescales of up to 1 day. The uptake coefficients for all three reactions are calculated for STS even when backscatter values indicate the presence of ice. However, no difference in $\mathrm{HCl}$ mixing ratios is evident when the uptake coefficients for ice are used once backscatter values suggest the presence of ice PSCs.

Figure $6 \mathrm{a}-\mathrm{c}$ shows backscatter, temperature, time below $T_{\text {NAT }}-3 \mathrm{~K}$ and time below $T_{\text {ICE }}$ for three different trajectories. These trajectories are initialized on 30 December at different locations so each of them would encounter their first maximum in backscatter on another day. Trajectory 1 (Fig. 6a) encounters its maximum on 31 December, Trajectory 2 (Fig. 6b) on 1 January and Trajectory 3 (Fig. 6c) on 2 January. Figure $6 \mathrm{~d}-\mathrm{f}$ then shows the calculated SAD, modeled $\mathrm{HCl}$ and $\mathrm{ClONO}_{2}$ for two different cases and observations by MLS along these trajectories.

The maximum backscatter suggests the presence of ice clouds when the trajectories encounter their first maximum in backscatter; however, temperatures only decrease below the frost point on 6 January for trajectory 1 which encountered its backscatter maximum on 31 December (Fig. 6a). This suggests that temperatures below the frost point might not be resolved by the used meteorological data. 


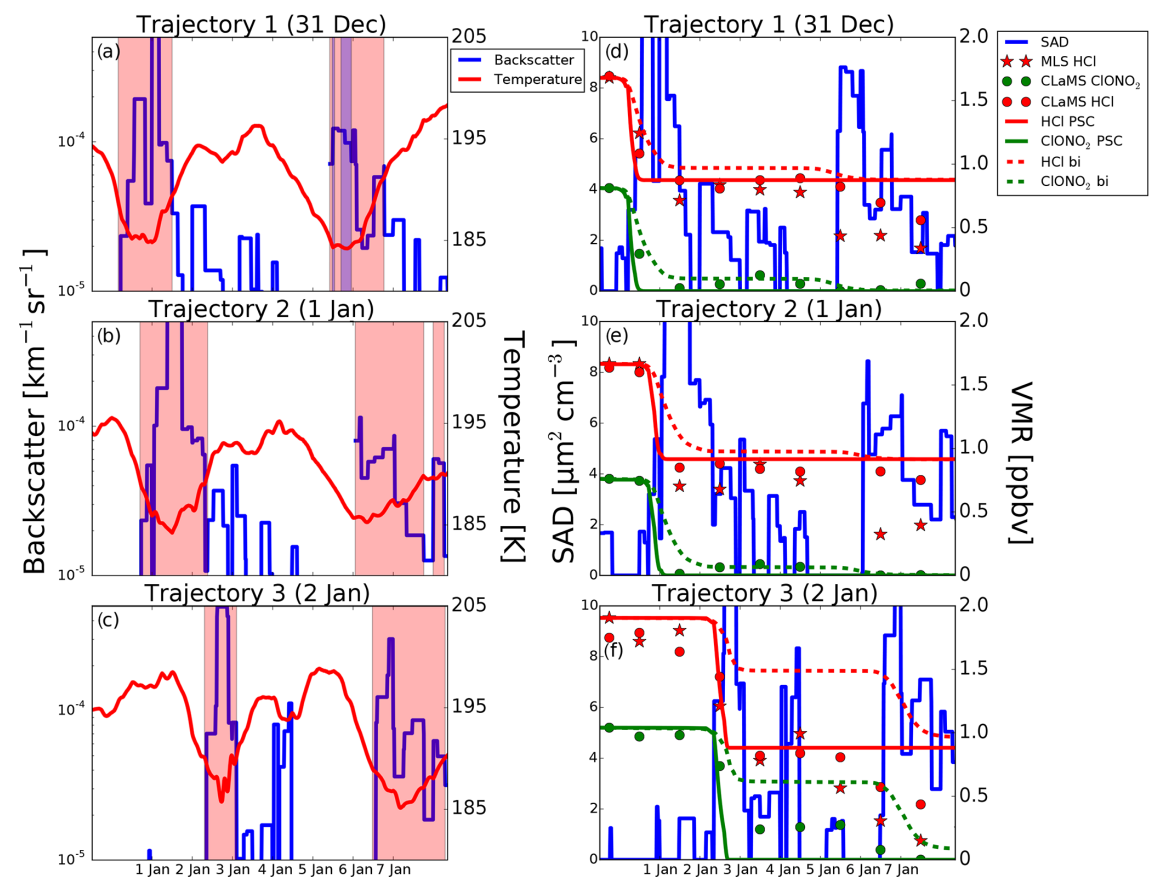

Figure 6. Temporal evolution of three trajectories on $510 \mathrm{~K}$ potential temperature which were initialized at the same time at different locations. The trajectories encounter their first maximum in backscatter on 31 December (a, d), 1 January (b, e) and 2 January (c, f), respectively. The period from 30 December 2009 to 8 January 2010 is shown for all three trajectories. Left column (a-c) shows backscatter (blue), temperature (red), time below $T_{\mathrm{NAT}}-3 \mathrm{~K}$ (red shading) and time below $T_{\mathrm{ICE}}$ (blue shading). Right column (d-f) shows surface area density (blue), $\mathrm{HCl}$ (red) and $\mathrm{ClONO}_{2}$ (green). Red stars are the daily mean $\mathrm{HCl}$ mixing ratios observed by MLS interpolated on the position of the trajectory and circles are CLaMS mixing ratios of $\mathrm{HCl}$ (red) and $\mathrm{ClONO}_{2}$ (green), respectively. Solid red and green lines represent $\mathrm{HCl}$ and $\mathrm{ClONO}_{2}$ where $\mathrm{SAD}$ for calculating heterogeneous reaction rates is calculated from the observed backscatter. Dashed red and green lines represent $\mathrm{HCl}$ and $\mathrm{ClONO}_{2}$ where $\mathrm{SAD}$ is calculated for a binary aerosol.

The evolution of modeled $\mathrm{HCl}$ and observations (Fig. 6df) shows very good agreement for the first activation phase. Nakajima et al. (2016) also reported very good agreement of model and observations during this phase. $\mathrm{HCl}$ along the trajectories deviates from the observations after a couple of days. However, chlorine activation in the first half of the trajectories can still be analyzed. A decrease in $\mathrm{HCl}$ coincides with an increase in surface area density and $\mathrm{ClONO}_{2}$ is totally depleted after the initial activation. This confirms that $\mathrm{ClONO}_{2}$ is indeed the limiting factor for chlorine activation because observed $\mathrm{HCl}$ also does not decrease further once the model shows complete removal of $\mathrm{ClONO}_{2}$. The complete removal of $\mathrm{ClONO}_{2}$ also occurs before the first maximum in surface area density (Fig. 6d-f), but activation starts when SAD increases above background values. Neither observations nor modeled chemistry indicate significant chlorine activation in the absence of PSCs. In fact, when heterogeneous chemistry is only modeled on a binary sulfate aerosol (without uptake of $\mathrm{HNO}_{3}$ as temperatures decrease) chlorine activation does not only progress slower (Fig. 6d-f, dashed lines) but also does not completely deplete $\mathrm{ClONO}_{2}$.

While previous studies have shown that for an entire winter season heterogeneous chemistry on cold binary aerosol is sufficient to achieve complete chlorine activation (Drdla and Müller, 2012; Wohltmann et al., 2013), in the case of a mesoscale event as described in this study chlorine activation on PSCs is faster than on the background aerosol. The observed activation could not have occurred without the additional surface area provided by PSCs. However, Fig. $6 f$ also shows that after 5 days, heterogeneous chemistry on only the binary aerosol has depleted all the initially available $\mathrm{ClONO}_{2}$. In agreement with Drdla and Müller (2012) the degree of chlorine activation on only the background aerosol would become indistinguishable from chlorine activation on PSCs after about 10 days, or the time it takes for an air parcel to fully circumnavigate the vortex twice.

\section{Conclusions}

We have analyzed CALIOP and MLS observations in combination with modeled trajectories to quantify the initial chlorine activation phase for the winter 2009/10 and constrain the spatial and temporal scales on which chlorine activation occurred; thus, this answers the question regarding the extent to which heterogeneous chemistry on PSC particles is responsible for chlorine activation and the timescales for this 
processing. Our analysis has shown that mesoscale PSCs can have a substantial effect on chlorine chemistry throughout the polar vortex, even though the PSCs themselves only cover a small fraction of the polar vortex. A substantial decrease in $\mathrm{HCl}$ is observed in air masses exposed to PSCs for about $24 \mathrm{~h}$. MLS observations indicate that air masses with low $\mathrm{HCl}$ mixing ratios occur downstream of this PSC event in agreement with the trajectory calculations. The modeled trajectories provide a solid approximation of the path the air has taken after it encountered the PSC and allow to distinguish between processed and unprocessed air masses. The average daily $\mathrm{HCl}$ mixing ratio shows substantially smaller $\mathrm{HCl}$ values in processed than in unprocessed air. We also show that chlorine activation in the polar vortex is not always a uniform process but can occur in mesoscale PSC "processing reactors". Heterogeneous chemistry occurs in these "processing reactors" and the air is subsequently advected and mixed throughout the vortex. Chlorine activation does not occur homogeneously throughout the vortex and $\mathrm{HCl}$ mixing ratios can vary significantly, especially during this initial activation phase. Therefore, a vortex average point of view does not provide an accurate representation during this phase. The trajectory calculations show that the availability of $\mathrm{ClONO}_{2}$ limits the extent of chlorine activation. For the first time, CALIOP backscatter observations were utilized to estimate surface area density and model heterogeneous chemistry along trajectories. Results from these simulations are in good agreement with observed mixing ratios of $\mathrm{HCl}$. These calculations also show that the SAD enhancements from PSCs lead to faster chlorine activation than would occur on the background aerosol. While the background aerosol could eventually activate the same amount of chlorine as the PSCs, over the time and spatial scales considered in this study, the observed rate of chlorine activation can only be explained by the additional surface area provided by PSCs. While this study focuses on the Arctic, similar conditions like the situation over Greenland in January 2010 can also occur over the Antarctic. Optically thick PSCs over Antarctica predominantly occur over the Antarctic peninsula; therefore, this area can also serve as a processing reactor for chlorine activation.

Acknowledgements. This work is funded under NASA's postdoctoral program administered by Oak Ridge Associated Universities. We are grateful to NASA for the MERRA meteorological analysis and EOS MLS and CALIOP teams for their high-quality data products. We also like to thank two anonymous reviewers for their comments which greatly improved the quality of the manuscript.

Edited by: F. Khosrawi

\section{References}

Carslaw, K. S., Luo, B., and Peter, T.: An analytic expression for the composition of aqueous $\mathrm{HNO}_{3}-\mathrm{H}_{2} \mathrm{SO}_{4}$ stratospheric aerosols including gas phase removal of $\mathrm{HNO}_{3}$, Geophys. Res. Lett., 22, 1887-1880, 1995.

Carslaw, K. S., Wirth, M., Luo, B. P., Dörnbrack, A., Leutbecher, M., Volkert, H., nad J. T. Bacmeister, W. R., Reimer, E., and Peter, T.: Increased stratospheric ozone depletion due to mountain-induced atmospheric waves, Nature, 391, 675-678, doi:10.1038/35589, 1998.

Curtius, J., Weigel, R., Vössing, H.-J., Wernli, H., Werner, A., Volk, C.-M., Konopka, P., Krebsbach, M., Schiller, C., Roiger, A., Schlager, H., Dreiling, V., and Borrmann, S.: Observations of meteoric material and implications for aerosol nucleation in the winter Arctic lower stratosphere derived from in situ particle measurements, Atmos. Chem. Phys., 5, 3053-3069, doi:10.5194/acp-5-3053-2005, 2005.

Dee, D. P., Uppala, S. M., Simmons, A. J., Berrisford, P., Poli, P., Kobayashi, S., Andrae, U., Balmaseda, M. A., Balsamo, G., Bauer, P., Bechtold, P., Beljaars, A. C. M., van de Berg, L., Bidlot, J., Bormann, N., Delsol, C., Dragani, R., Fuentes, M., Geer, A. J., Haimberger, L., Healy, S. B., Hersbach, H., Hólm, E. V., Isaksen, L., Kållberg, P., Köhler, M., Matricardi, M., McNally, A. P., Monge-Sanz, B. M., Morcrette, J.-J., Park, B.-K., Peubey, C., de Rosnay, P., Tavolato, C., Thépaut, J.-N., and Vitart, F.: The ERA-Interim reanalysis: configuration and performance of the data assimilation system, Q. J. Roy. Meteor. Soc., 137, 553-597, doi:10.1002/qj.828, 2011.

Drdla, K. and Müller, R.: Temperature thresholds for chlorine activation and ozone loss in the polar stratosphere, Ann. Geophys., 30, 1055-1073, doi:10.5194/angeo-30-1055-2012, 2012.

Fahey, D. W., Gao, R. S., Carslaw, K. S., Kettleborough, J., Popp, P. J., Northway, M. J., Holecek, J. C., Ciciora, S. C., McLaughlin, R. J., Thompson, T. L., Winkler, R. H., Baumgardner, D. G., Gandrud, B., Wennberg, R. O., Dhaniyala, S., McKinney, K., Peter, T., Salawitch, R. J., Bui, T. P., Elkins, J. W., Webster, C. R., Atlas, E. L., Jost, H., Wilson, J. C., Herman, R. L., Kleinböhl, A., and von König, M.: The detection of large $\mathrm{HNO}_{3}$-containing particles in the winter Arctic stratosphere, Science, 291, 1026-1031, doi:10.1126/science.1057265, 2001.

Gobbi, G. P.: Lidar estimation of stratospheric aerosol properties: Surface, volume and extinction to backscatter ratio, J. Geophys. Res., 100, 11219-11235, doi:10.1029/94JD03106, 1995.

Grooß, J.-U., Günther, G., Konopka, P., Müller, R., McKenna, D. S., Stroh, F., Vogel, B., Engel, A., Müller, M., Hoppel, K., Bevilacqua, R., Richard, E. an Webster, C. R., J. W. Elkins, Hurst, D. F., Romashkin, P. A., and Baumgardner, D. G.: Simulation of ozone depletion in spring 2000 with the Chemical Lagrangian Model of the Stratosphere (CLaMS), J. Geophys. Res., 107, 8295, doi:10.1029/2001JD000456, 2002.

Grooß, J.-U., Engel, I., Borrmann, S., Frey, W., Günther, G., Hoyle, C. R., Kivi, R., Luo, B. P., Molleker, S., Peter, T., Pitts, M. C., Schlager, H., Stiller, G., Vömel, H., Walker, K. A., and Müller, R.: Nitric acid trihydrate nucleation and denitrification in the Arctic stratosphere, Atmos. Chem. Phys., 14, 1055-1073, doi:10.5194/acp-14-1055-2014, 2014.

Junge, C. E., Chagnon, C. W., and Manson, J. E.: Stratospheric aerosols, J. Meteorol., 18, 81-108, 1961. 
Kelly, K. K., Tuck, A. F., Murphy, D. M., Proffitt, M. H., Fahey, D. W., Jones, R. L., McKenna, D. S., Loewenstein, M., Podolske, J. R., Strahan, S. E., Ferry, G. V., Chan, K. R., Vedder, J. F., Gregory, G. L., Hypes, W. D., McCormick, M. P., Browell, E. V., and Heidt, L. E.: Dehydration In The Lower Antarctic Stratosphere During Late Winter And Early Spring, 1987, J. Geophys. Res., 94, 11317-11357, doi:10.1029/JD094iD09p11317, 1989.

Kirner, O., Müller, R., Ruhnke, R., and Fischer, H.: Contribution of liquid, NAT and ice particles to chlorine activation and ozone depletion in Antarctic winter and spring, Atmos. Chem. Phys., 15, 2019-2030, doi:10.5194/acp-15-2019-2015, 2015.

Kühl, S., Dörnbrack, A., Wilms-Grabe, W., Sinnhuber, B.-M., Platt, U., and Wagner, T.: Observational evidence of rapid chlorine activation by mountain waves above northern Scandinavia, J. Geophys. Res., 109, D22309, doi:10.1029/2004JD004797, 2004.

Lambert, A., Santee, M. L., Wu, D. L., and Chae, J. H.: A-train CALIOP and MLS observations of early winter Antarctic polar stratospheric clouds and nitric acid in 2008, Atmos. Chem. Phys., 12, 2899-2931, doi:10.5194/acp-12-2899-2012, 2012.

Livesey, N. J., Read, W. G., Froidevaux, L., Lambert, A., Manney, G. L., Pumphrey, H. C., Santee, M. L., Schwartz, M. J., Wang, S., Cofeld, R. E., Cuddy, D. T., Fuller, R. A., Jarnot, R. F., Jiang, J. H., Knosp, B. W., Stek, P. C., Wagner, P. A., and Wu, D. L.: Version 3.3 Level 2 data quality and description document, Technical Report JPL D-33509, Jet Propulsion Laboratory, 2011.

Lowe, D. and MacKenzie, A. R.: Polar stratospheric cloud microphysics and chemistry, J. Atmos. Sol.-Terr. Phy., 70, 13-40, 2008.

McKenna, D. S., Konopka, P., Grooß, J.-U., Günther, G., Müller, R., Spang, R., Offermann, D., and Orsolini, Y.: A new Chemical Lagrangian Model of the Stratosphere (CLaMS): 1.Formulation of advection and mixing, J. Geophys. Res., 107, 4309, doi:10.1029/2000JD000114, 2002.

Nakajima, H., Wohltmann, I., Wegner, T., Takeda, M., Pitts, M. C., Poole, L. R., Lehmann, R., Santee, M. L., and Rex, M.: Polar stratospheric cloud evolution and chlorine activation measured by CALIPSO and MLS, and modeled by ATLAS, Atmos. Chem. Phys., 16, 3311-3325, doi:10.5194/acp-16-3311-2016, 2016.

Nash, E. R., Newman, P. A., Rosenfield, J. E., and Schoeberl, M. R.: An objective determination of the polar vortex using Ertel's potential vorticity, J. Geophys. Res., 101, 9471-9478, 1996.

Pitts, M. C., Poole, L. R., and Thomason, L. W.: CALIPSO polar stratospheric cloud observations: second-generation detection algorithm and composition discrimination, Atmos. Chem. Phys., 9, 7577-7589, doi:10.5194/acp-9-7577-2009, 2009.

Pitts, M. C., Poole, L. R., Dörnbrack, A., and Thomason, L. W.: The 2009-2010 Arctic polar stratospheric cloud season: a CALIPSO perspective, Atmos. Chem. Phys., 11, 2161-2177, doi:10.5194/acp-11-2161-2011, 2011.

Pitts, M. C., Poole, L. R., Lambert, A., and Thomason, L. W.: An assessment of CALIOP polar stratospheric cloud composition classification, Atmos. Chem. Phys., 13, 2975-2988, doi:10.5194/acp-13-2975-2013, 2013.

Portmann, R. W., Solomon, S., Garcia, R. R., Thomason, L. W., Poole, L. R., and McCormick, M. P.: Role of aerosol variations in anthropogenic ozone depletion in the polar regions, J. Geophys. Res., 101, 22991-23006, 1996.

Rienecker, M. M., Suarez, M. J., Gelaro, R., Todling, R., Bacmeister, J., Liu, E., Bosilovich, M. G., Schubert, S. D., Takacs,
L., Kim, G.-K., Bloom, S., Chen, J., Collins, D., Conaty, A., da Silva, A., Gu, W., Joiner, J., Koster, R. D., Lucchesi, R., Molod, A., Owens, T., Pawson, S., Pegion, P., Redder, C. R., Reichle, R., Robertson, F. R., Ruddick, A. G., Sienkiewicz, M., and Woollen, J.: MERRA: NASA's Modern-Era Retrospective Analysis for Research and Applications, J. Climate, 24, 3624-3648, doi:10.1175/JCLI-D-11-00015.1, 2011.

Santee, M. L., Lambert, A., Read, W. G., Livesey, N. J., Manney, G. L., Cofield, R. R., Cuddy, D. T., Daffer, W. H., Froidevaux, L., Fuller, R. A., Jarnot, R. F., Knosp, B. W., Perun, V. S., Snyder, W. V., Stek, P. C., Thurstans, R. P., Wagner, P. A., Waters, J. W., Connor, B., Urban, J., Murtagh, D., Ricaud, P., Barret, B., Kleinböhl, A., J, K., Küllmann, H., von Hobe, M., Toon, G. C., and Stachnik, R. A.: Validation of the Aura Microwave Limb Sounder ClO measurements, J. Geophys. Res, 113, D15S22, doi:10.1029/2007JD008762, 2008.

Solomon, S.: Stratospheric ozone depletion, A review of concepts and history, Rev. Geophys., 37, 275-316, 1999.

Solomon, S., Garcia, R. R., Rowland, F. S., and Wuebbles, D. J.: On the depletion of Antarctic ozone, Nature, 321, 755-758, 1986.

Stephens, G. L., Vane, D., Boain, R., Mace, G., Sassen, K., Wang, Z., Illingworth, A., O'Connor, E., Rossow, W., Durden, S., Miller, S., Austin, R., Benedetti, A., Mitrescu, C., and Team, C. S.: The CloudSat mission and the A-Train: A new dimension of space-based observations of clouds and precipitation, B. Am. Meteorol. Soc., 83, 1771-1790, doi:10.1175/BAMS-83-121771, 2002.

Waters, J. W., Froidevaux, L., Harwood, R. S., Jarnot, R. F., Pickett, H. M., Read, W. G., Siegel, P. H., Cofield, R. R., Filipak, M. J., Flower, D. A., Holden, J. R., Lau, G. K., Livesey, N. J., Manney, G. L., Pumphrey, H. C., Santee, M. L., Wu, D. L., Cuddy, D. T., Lay, R. R., Loo, M. S., Perun, C. S., Schwartz, M. J., Stek, P. C., Thurstans, R. P., Boyles, M. A., Chandra, K. M., Chavez, M. C., Chen, G.-S., Chudasama, B. V., Dodge, R., Fuller, R. A., Girard, M. A., Jiang, J. H., Jiang, Y., Knosp, B. W., LaBelle, R. C., Lam, J. C., Lee, K. A., Miller, D., Oswald, J. E., Patel, N. C., Pukala, D. M., Quintero, O., Scaff, D. M., Snyder, W. V., Tope, M. C., Wagner, P. A., and Walch, M. J.: The Earth Observing System Microwave Limb Sounder (EOS MLS) on the Aura Satellite, IEEE T. Geosci. Remote, 44, doi:10.1109/TGRS.2006.873771, 2006.

Wegner, T., Grooß, J.-U., von Hobe, M., Stroh, F., SuminskaEbersoldt, O., Volk, C. M., Hösen, E., Mitev, V., Shur, G., and Müller, R.: Heterogeneous chlorine activation on stratospheric aerosols and clouds in the Arctic polar vortex, Atmos. Chem. Phys., 12, 11095-11106, doi:10.5194/acp-12-11095-2012, 2012.

Winker, D. M., Vaughan, M. A., Omar, A., Hu, Y., Powell, K. A., Liu, Z., Hunt, W. H., and Young, S. A.: Overview of the CALIPSO Mission and CALIOP Data Processing Algorithms, J. Atmos. Ocean. Tech., 26, 2310-2323, doi:10.1175/2009JTECHA1281.1, 2009.

Wohltmann, I., Wegner, T., Müller, R., Lehmann, R., Rex, M., Manney, G. L., Santee, M. L., Bernath, P., Suminska-Ebersoldt, O., Stroh, F., von Hobe, M., Volk, C. M., Hösen, E., Ravegnani, F., Ulanovsky, A., and Yushkov, V.: Uncertainties in modelling heterogeneous chemistry and Arctic ozone depletion in the winter 2009/2010, Atmos. Chem. Phys., 13, 3909-3929, doi:10.5194/acp-13-3909-2013, 2013. 